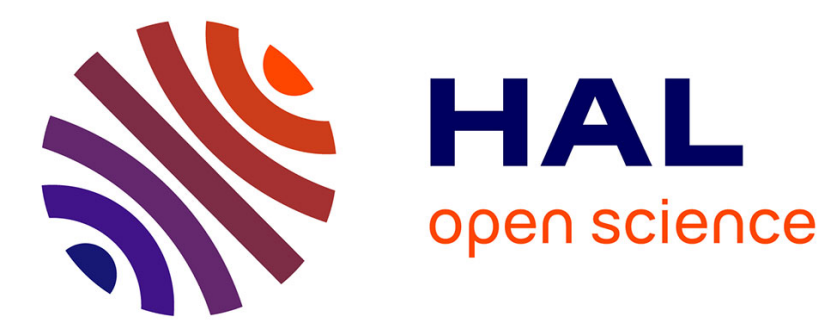

\title{
STRENGTH AND DUCTILITY OF WELDED JOINTS WITH AUSTENITIC AND MARAGING FILLER METALS UNDER DYNAMIC TENSILE LOADING
}

\author{
L. Meyer
}

\section{- To cite this version:}

L. Meyer. STRENGTH AND DUCTILITY OF WELDED JOINTS WITH AUSTENITIC AND MARAGING FILLER METALS UNDER DYNAMIC TENSILE LOADING. Journal de Physique Colloques, 1988, 49 (C3), pp.C3-35-C3-40. 10.1051/jphyscol:1988305 . jpa-00227721

\section{HAL Id: jpa-00227721 https://hal.science/jpa-00227721}

Submitted on 1 Jan 1988

HAL is a multi-disciplinary open access archive for the deposit and dissemination of scientific research documents, whether they are published or not. The documents may come from teaching and research institutions in France or abroad, or from public or private research centers.
L'archive ouverte pluridisciplinaire HAL, est destinée au dépôt et à la diffusion de documents scientifiques de niveau recherche, publiés ou non, émanant des établissements d'enseignement et de recherche français ou étrangers, des laboratoires publics ou privés. 


\title{
STRENGTH AND DUCTILITY OF WELDED JOINTS WITH AUSTENITIC AND MARAGING FILLER METALS UNDER DYNAMIC TENSILE LOADING
}

\author{
L.W. MEYER \\ IFAM - Fraunhofer-Institut für Angewandte Materialforschung, \\ Lesumer Heerstrasse 36, D-282 Bremen-Lesum, F.R.G.
}

\begin{abstract}
RÉSUMÉ - Le comportement á la résistance et à la déformation de deux aciers faiblement alliés et à haute résistance typ 45CDV6-7, ainsi que des liaisons soudées en aciers austénitique et martensitique à durcissement structural, a été étudié en sollicitations dynamiques de traction avec trois vitesses d'essais jusqu'à $\xi=5 \cdot 10^{2}$ s Tous les matériaux et liaisons soudées ont présenté une augmentation de la limite élastique et de la résistance à la traction, sans que l'on observe à vitesse plus élevée une diminution de la capacité à la déformation ou de la revirement de la mécanisme du rupture.
\end{abstract}

\begin{abstract}
The strength and deformation behaviour of base metai and welded specimens have been investigated using impact tensile loading. These tests have been performed on two quenched and tempered low alloy steels of different hardness and on shielded arc weld joined with austenitic and maraging filler metals. With increasing strain rate the yield strength and UTS of all base metals and welded joints were enhanced, but no reduction of ductility resp. no change in fracture mode has been observed.
\end{abstract}

\section{INTRODUCTION}

The aim of this work was to establish the best method of welding for a construction where an intense dynamic loading has to be taken into account. The construction is expected to fail only after a reasonable amount of energy consumption and not with a more or less brittle fracture.

One problem to solve was to weld a high strength base metal with a relative high carbon aquivalent of about 1 \% without the occurance of cracks in the heat effected zone or in the weldments. This was reached by shielded arc welding and by preheating of the plates up to $150^{\circ} \mathrm{C}$.

The second question was, which kind of filler metals, an austenitic or a maraging type will yield to the best performance in strength and ductility under tensile loading at low, medium and high rates of strain. 


\section{IIJESTYGATED MATERIALS AND TEST PROCEDURE}

To establish an extended basis for a valuation the base metal was investigated for two levels of hardnesses $(510$ and $420 \mathrm{HV} 30)$. The high hardness version was used for the welding, which was done with a maraging and an austenitic electrode. Because partially a heat treatmerit was used for annealing the joints, five materials have been investigated separately, tab. 1. Three levels of strain rates were used: quasistatic with $\varepsilon=5 \cdot 10^{-4} s^{-1}$, medium with $\dot{\varepsilon}=5 \cdot 10^{-1} \mathrm{~s}^{-1}$ and high with $\varepsilon=5 \cdot 10^{2} \mathrm{~s}^{-1}$ or more.

The gage length and the diameter for all tensile specimens was the same (length $18 \mathrm{~mm}$; diameter $3,56 \mathrm{~mm}$ ).

Tab. 1 : Welding parameter and materials

\begin{tabular}{|c|c|c|c|c|c|}
\hline & $\begin{array}{l}\text { Welding filler } \\
\text { austenitic }\end{array}$ & $\begin{array}{l}\text { metal } \\
\text { maraging w.h. }\end{array}$ & maraging & $\begin{array}{r}\text { Base met } \\
510 \text { HV } 30 \\
\end{array}$ & $\begin{array}{l}\text { al } \\
420 \mathrm{HV} 30\end{array}$ \\
\hline Material No. & 1 & 2 & 3 & 4 & 5 \\
\hline plate thickness & $14 \mathrm{~mm}$ & $12 \mathrm{~mm}$ & $12 \mathrm{~mm}$ & $12 \mathrm{~mm}$ & $12 \mathrm{~mm}$ \\
\hline Base metal & No. 4 & No. 4 & No. 4 & & \\
\hline $\begin{array}{l}\text { Welding parameter: } \\
\text { filler metal name } \\
\text { DIN-description } \\
\text { electrode-diam. } \\
\text { protective gas } \\
\text { gas rate } \\
\text { welding current } \\
\text { welding voltage } \\
\text { welding velocity } \\
\text { preheating } \\
\text { cross-section of } \\
\text { weld } \\
\text { heat treatment } \\
\text { after welding }\end{array}$ & $\begin{array}{l}\text { Thermanit } x \\
\text { x15CrNimn } 188 \\
1,2 \mathrm{~mm} \\
\text { argon } \\
18 \mathrm{ltr} / \mathrm{min} \\
250 \mathrm{~A} \\
28-29 \mathrm{~V} \\
60 \mathrm{~cm} / \mathrm{min} \\
100-150^{\circ} \mathrm{C} \\
\mathrm{V} \\
\text { without gap } \\
450^{\circ} \mathrm{C} 1 \mathrm{~h} / \mathrm{air}\end{array}$ & $\begin{array}{l}\text { Novonit } \\
\text { HFX750 } \\
\text { X2NiCoMo } 1885 \\
1,2 \mathrm{~mm} \\
\text { argon } \\
15 \mathrm{ltr} / \mathrm{min} \\
230-250 \mathrm{~A} \\
25-27 \mathrm{~V} \\
60 \mathrm{~cm} / \mathrm{min} \\
100-150^{\circ} \mathrm{C} \\
\mathrm{V} \\
\text { with } 1 \mathrm{~mm} \text { gap } \\
450^{\circ} \mathrm{C} 1 \mathrm{~h} / \mathrm{air}\end{array}$ & $\begin{array}{l}\text { Novonit } \\
\text { HFX750 } \\
\text { X2NiCoMo1885 } \\
1.2 \mathrm{~mm} \\
\text { argon } \\
151 \mathrm{tr} / \mathrm{min} \\
240-250 \mathrm{~A} \\
25-26 \mathrm{~V} \\
56 \mathrm{~cm} / \mathrm{min} \\
100-150^{\circ} \mathrm{C} \\
\mathrm{V} \\
\text { with } 1 \mathrm{~mm} \mathrm{gap} \\
-\end{array}$ & $\begin{array}{l}\text { no } \\
\text { welding }\end{array}$ & $\begin{array}{l}\text { no } \\
\text { welding }\end{array}$ \\
\hline
\end{tabular}

From the welded joints the small tensile specimen were cut out of the center of the plates containing a length of $8-10 \mathrm{~mm}$ of filler metal, Fig. 1. This is regarded as the necessary length for a nearly free deformation of the welded area, but with a rest of a support effect by the base metal, similar to the reality.

The strains are measured with $0,6 \mathrm{~mm}$ strain gages, attached to the weld resp. in the mid of the gage length. With a separate force measurement device, located directly behind the specimen, force resp. stress-strain-diagrams up to $\dot{\varepsilon}=5 \cdot 10^{2} \mathrm{~s}^{-1}$ are obtained. For higher strain rates a force measurement at the specimen itself is used, [1]. All materials are tested at room temperature. 


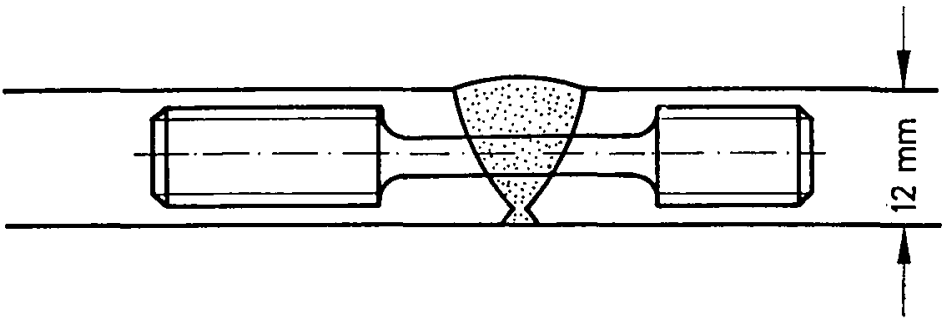

Fig. 1 : Sampling crosswise to the welded joints

\section{STRESS-STRAIN-BEHAVIOUR UNDER TENSILE LOADING}

At quasistatic loading the base metal $45 \mathrm{Cr}$ Mo V 67 exhibits a linearelastic behaviour up to $\sigma=1250 \mathrm{MPa}$ and after a stronger deformation strengthening a 2 yield strength of $\sigma_{y}=1500 \mathrm{MPa}$. The following strengthening is low, fig. 2. At medium strain rates the yield stresses are increased slightly, but then a stronger strain rate sensitivity takes place, the Hookean solid is extended to about $0=1400 \mathrm{MPa}$ and the yield strength reaches nearly $\sigma_{y}=1700 \mathrm{MPa}$.

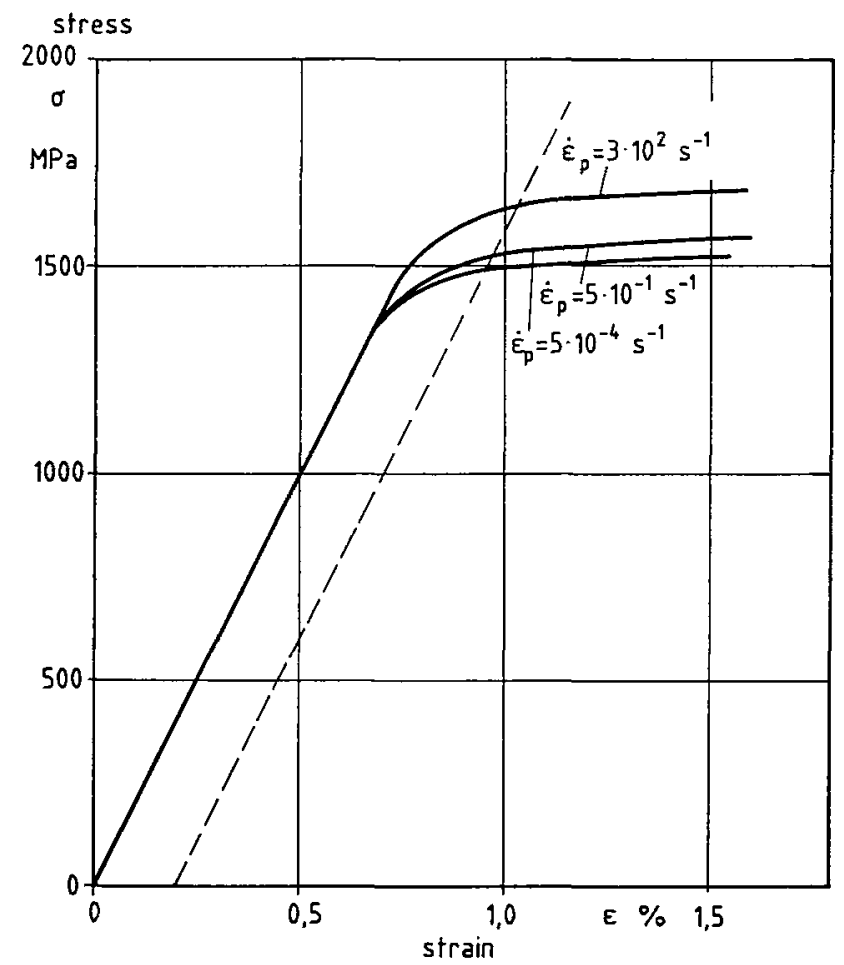

Fig. 2 : Stress-strain behaviour of base metal $45 \mathrm{Cr}$ Mo $\mathrm{V} 67$ with a hardness of $510 \mathrm{HV} 30$ at three rates of strain 
The same dependence of the yield strength and UTS versus the strain rate - a velocity independent region up to $\dot{E} \mathrm{p}=10^{0} \mathrm{~s}^{-1}$, followed by a rate sensitive region at higher loading rates - is presented by the base metal with the lower hardness of $420 \mathrm{HV} 30$, fig. 3. The yield strength and UTS is reduced adequately for about $250 \mathrm{MPa}$.

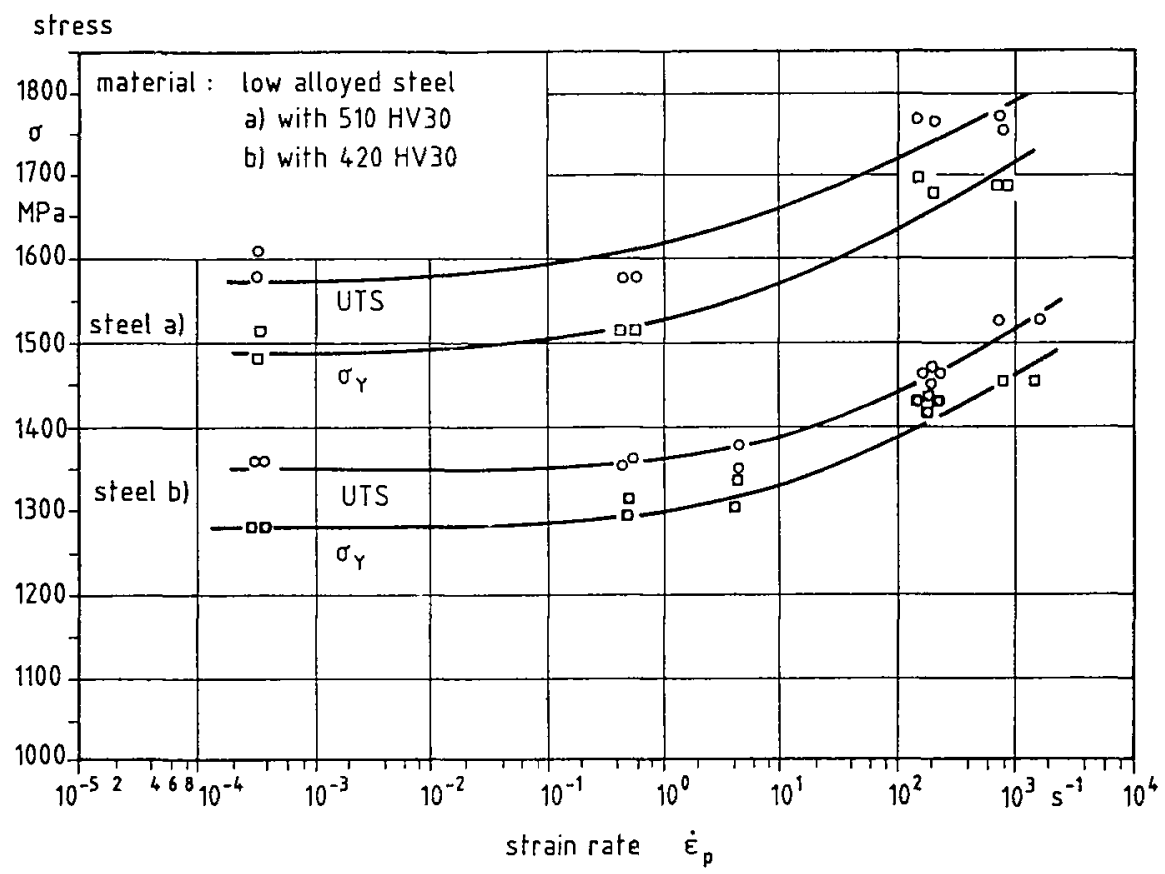

Fig. 3 : .2 yield strength oy and UTS versus strain rate of base metal $45 \mathrm{Cr}$ Mo $\mathrm{V} 67$ in two grades of hardness

Compared with the base metals, the weldment with the austenitic filler metal, fig. 4, exhibits a reduced yield strength and UTS, but for welding, the static yield stress of nearly $500 \mathrm{MPa}$ is acceptable.

Similar to an austenitic base metal [2] the strain rate sensitivity of $\sigma_{y}$ and UTS increases continously with enhancing strain rate.

This tendency is the same for the welded joints with maraging filler metal, where the insensitive range of strain rate does not exist, fig. 5. But, the UTS of quasistatic loading reaches for the annealed and not annealed state with $1350 \mathrm{MPa}$ the identical UTS level of the weak base metal.

Of course, the yield strength with $\sigma_{y}=1140 \mathrm{MPa}$ and $1210 \mathrm{MPa}$ is slightly lower compared with $\sigma_{y}=1280 \mathrm{MPa}$ of the low hardness base metal. But the strain rate sensitivity do/dé of the welded joints is higher than of the weak base metal. This leads to the effect, that at strain rates between $10^{2}$ and $10^{3} \mathrm{~s}^{-1}$ the not annealed and annealed maraging weldment, No. 3 and 2 , exceeds the strength of the weak base metal, resp. lies in between the strength of both base metals, fig.6, No. 4 and No. 5 . 
stress

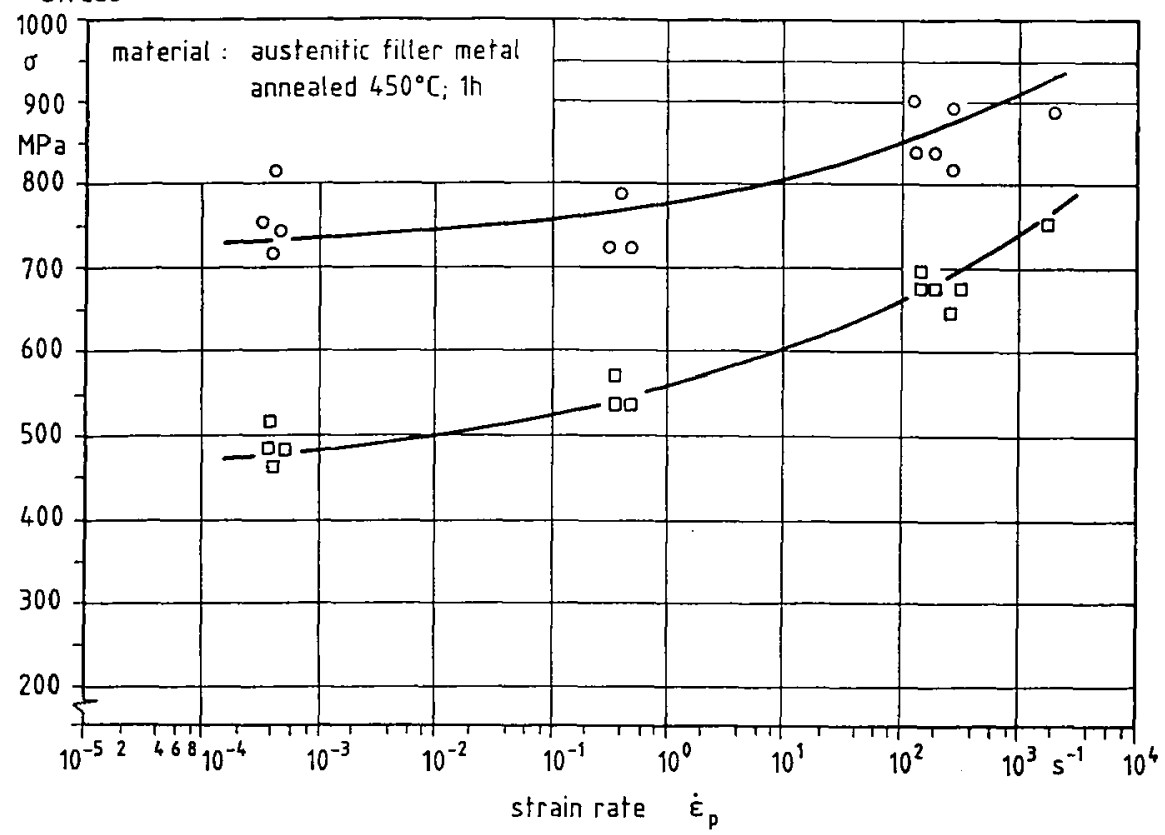

rig. 4: 2 yield strength $\sigma_{y}$ and UTS versus strain rate $\dot{\varepsilon}_{\mathrm{p}}$ of austenitic weld metal in annealed state

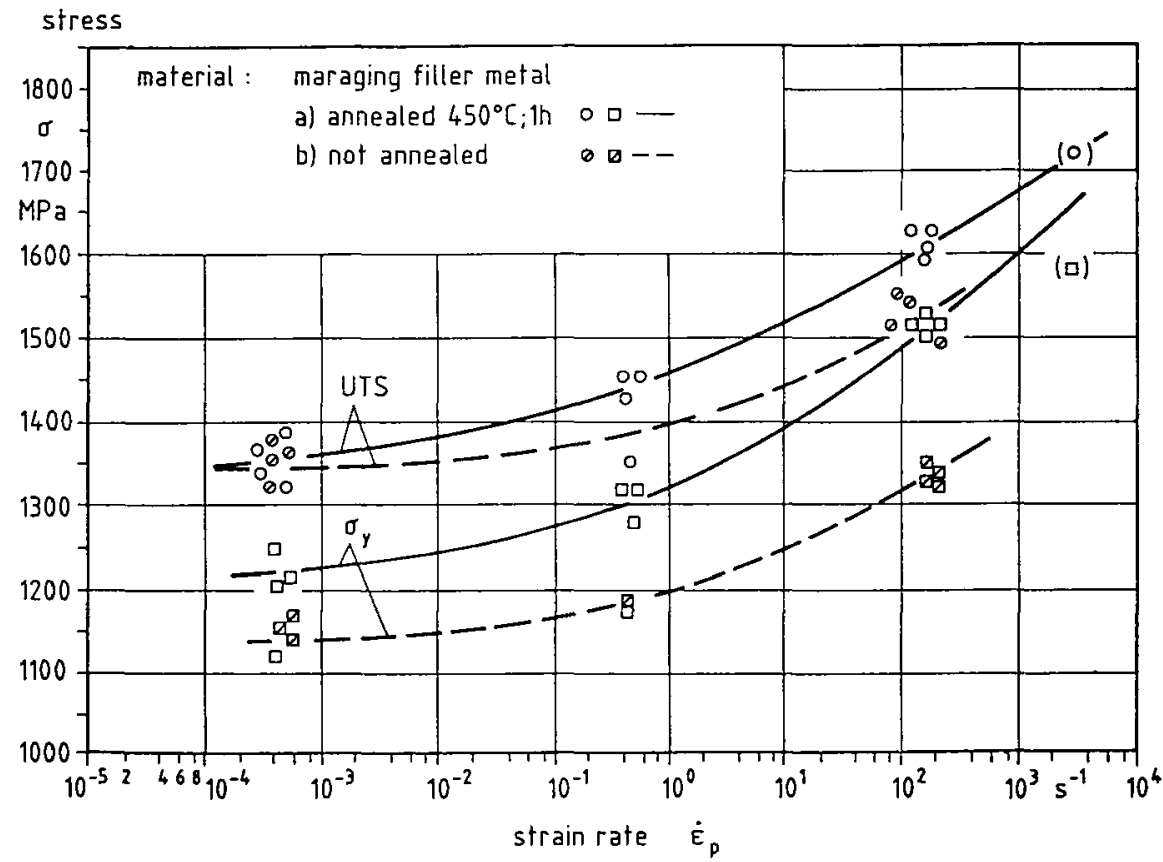

Fig. 5: .2 yield strength oy and UTS versus strain rate $\dot{\varepsilon}_{\mathrm{p}}$ of maraging weld metal in annealed and not annealed state 


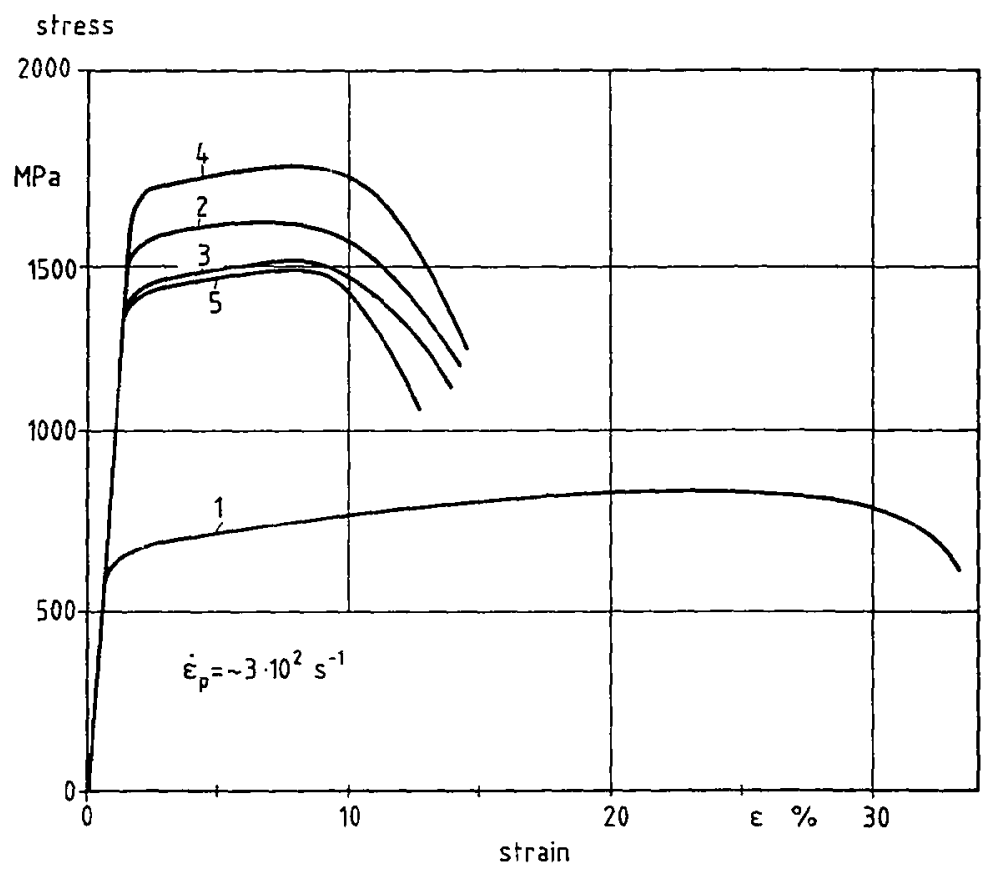

Fig. 6: Stress-strain-behaviour at $\dot{\varepsilon}_{\mathrm{p}}=3 \cdot 10^{2} \mathrm{~s}^{-1}$ of the two base metals (No. 4 and 5 ) and the weldments (austenitic filler No.1; maraging filler without heat treatment No. 2 and maraging filler with heat treatment No. 3)

\section{SUMMARY}

This behaviour may be regarded as a respectable achievement, because -in addition- the ductility reaches the same amount as the base metals Therefore a homogenous behaviour of a construction loaded dynamically will be guaranteed.

If a larger deformability combined with an extended homogenous strain is desired, then the austenitic filler should be chosen. The fracture strain exceeds more than $30 \%$, but the flow stress is reduced to about half of that of the maraging filler metal.

Under all conditions and materials, the fracture mode remains a ductile one. An embrittlement caused by the high strain rates doesn't occur.

\section{REFERENCES}

/1/ Meyer, L.W., Titanium, Science and Technology, DGM, Oberursel, West-Germany, p. 1851 (1985)

/2/ Meyer, L.W., Kunze, H.-D., and Seifert, K., Shock Waves and High Strain Rate Phenomena in Metals, Plenum Press, New York, p. 51 (1981) 